\title{
Tantangan dalam Mengefektifkan Pembangkit Tenaga Air Skala Kecil
}

\author{
Hermagasantos Zein ${ }^{1}$, Siti Saodah ${ }^{1}$, Ali Mashar ${ }^{1}$, I.Made Wiwit ${ }^{1}$, Djafar Sodiq ${ }^{1}$, \\ Aceng Daud ${ }^{1}$, Erwin Yusuf ${ }^{1}$, Ahmad Mudawari $^{1}$, Ahmad Deni $^{1}$ \\ ${ }^{1}$ Jurusan Teknik Konversi Energi, Politeknik Negeri Bandung \\ email : hermaga_s@yahoo.co.id, siti.saodah@polban.ac.id
}

\begin{abstract}
Abstrak
Air adalah salah sumber tenaga listrik berdasarkan siklus alami. Air sebagai tenaga listrik telah lama dieksplorasi yang umumnya berskala besar karena lebih ekonomis. Akhir-akhir ini, pemanfaatan tenaga air berskala kecil mulai mendapat perhatian karena menipisnya sumber bahan bakar fosil. Secara teknis, pembangkit listrik tenaga air sekala kecil banyak yang menghadapi permasalahan, diantaranya adalah pemahaman tentang teknologi tenaga air dan pentingnya perawatan, dan kualitas listrik. Pengoptimalan tegangan sistem saluran dan dummy load diturunkan secara matematik secara jelas. Formulasiformulasinya telah diterapkan di Pembangkit Listrik Tenaga Mikrohydro Suralaya, Jawa Barat, dengan memperbaiki tegangan sistem dari 220 V ke $1 \mathrm{kV}$ untuk memenuhi tegangan dan rugi-rugi saluran. Sedangkan kapasitas dummy load optimalnya adalah $26 \mathrm{~kW}$, ini lebih kecil dari kapasitas terpasang $50 \mathrm{~kW}$.
\end{abstract}

Kata Kunci: PLTMH, perawatan, tegangan, frekuensi

\section{PENDAHULUAN}

Air telah dikenal sejak manusia ada. Manusia mulai menggunakan tenaga air dalam transportasi yang memanfaatkan arus sungai. Penggunaan tenaga air sangat sederhana adalah berupa kincir air [1] yang awal untuk menumbuk gabah/kopi dengan prinsip teknologi Lesung Padi, penggunaan lebih modern adalah untuk membangkitkan listrik yang dikenal dengan Kincir Air Listrik.

Penggunaan tenaga air modern telah dikembangkan dengan teknologi maju berupa berbagai variasi turbin air untuk mendapatkan efisiensi dari berbagai karakteristik tinggi air jatuh. Tenaga air akan lebih murah untuk daya yang besar (seperti PLTA Saguling 797,36 MW yang ditopang oleh 7 sub-unit pembangkit). Keuntungan lain adalah PLTA tergolong pada pembangkit bersih (green generating). Secara umum biaya pembangunan PLTA dapat dilihat dari Tabel 1, [2].

Tabel 1. Tipikal biaya instalasi dan biaya listrik diratakan.

\begin{tabular}{|c|c|c|c|c|}
\hline $\begin{array}{c}\text { Jenis } \\
\text { Tenaga Air }\end{array}$ & $\begin{array}{c}\text { Biaya } \\
\text { Instalasi } \\
(\mathrm{USD} / \mathrm{kW})\end{array}$ & $\begin{array}{c}\text { Biaya O\&M } \\
(\% / \text { tahun dari } \\
\text { biaya } \\
\text { instalasi) }\end{array}$ & $\begin{array}{c}\text { Faktor } \\
\text { Kapasit } \\
\text { as (\%) }\end{array}$ & $\begin{array}{c}\text { Biaya Listrik } \\
\text { Diratakan } \\
(2010 \text { USD / } \\
\text { kWh) }\end{array}$ \\
\hline PLTA Besar & $1050-7650$ & $2-2.5$ & $25-90$ & $0.02-0.19$ \\
\hline PLTA Kecil & $1300-8000$ & $1-4$ & $20-95$ & $0.02-0.27$ \\
\hline $\begin{array}{c}\text { Renovasi / } \\
\text { peningkatan }\end{array}$ & $500-1000$ & $1-6$ & & $0.01-0.05$ \\
\hline
\end{tabular}

Upaya mengurangkan pembangkit kotor (pollutant generating), maka upaya menambah kapasitas pembangkit listrik dari sumber energi baru dan terbarukan (EBT) menjadi perhatian Indonesia [3] dengan harapan pada tahun 2025 adalah 24,4\%. Ini merupakan semangat untuk mengembangkan tenaga air kecil, walaupun harga energinya masih belum dapat bersaing dengan energi batu bara (lihat Tabel 1).

Secara teknologi pembangkit air berskala kecil adalah sederhana [4] [5], namun persoalan yang muncul cukup rumit seperti kontrol tegangan dan frekuensi. Ini disebabkan oleh sebuah pembangkit air sekala kecil pada umumnya bekerja sendiri. Pembangkit harus dapat merespon perubahan beban (berupa penerangan rumah penduduk desa dimana pembangkit dibangun) dengan menjamin pasokan listrik yang stabil. Perubahan pemakaian listrik oleh penduduk sangat bervariatif, terutama antara siang dan malam. Sedangkan teknologi pembangkitnya adalah sangat sederhana, yaitu sudu turbin adalah tetap dan tanpa pengatur air masuk (guide vane), dan generator dengan medan tetap. Ini menunjukkan bahwa energi input air adalah konstan, sehingga tegangan dan frekuensi listrik sangan sensitif terhadap perubahan bebannya. Salah satu cara untuk mengatasi ini adalah membuat beban generator tetap, yaitu dengan mengombinasikan beban riil (beban rumah penduduk) dengan beban dummy [6]. Realisasi ini dibutuhkan kontrol pada beban dummy.

Satu masalah lain adalah lokasi antara pembangkit dan rumah penduduk adalah cukup jauh. Umumnya tegangan PLTA sekala kecil adalah 380/220 V, sehingga untuk mentransmisikan daya lebih dari $1 \mathrm{~km}$ akan mengalami tegangan jatuh yang besar. Ini akan mempengaruhi rugi-rugi jaringan seperti yang telah dikaji oleh [7], dimana rugi-rugi jaringan distribusi tidak boleh melebihi standar yang berlaku (umumnya tidak melebihi 4\%). Akibat panjangnya saluran PLTA skala kecil tersebut (sekitar $5 \mathrm{~km}$ ) maka efisiensi saluran menjadi jelek (bisa dibawah 70\%). Tidak saja efisiensi yang jelek, tetapi tegangan listrik di sisi pemakai turun dibawah tegangan minimum peralatan sehingga listrik tidak dapat digunakan oleh penduduk, seperti mikrohydro di Suryalaya dengan tegangan pada rumah penduduk $140 \mathrm{~V}$ dari sumber $220 \mathrm{~V}$ sebagai akibat jarak saluran $5 \mathrm{~km}$.

Hal yang lain yang harus diperhatikan adalah perawatan dan operasi dari PLTA sekala kecil tersebut. Ini adalah bagian yang penting untuk dipahami karena sumber daya di desa masih minim pengetahuan. Sumber daya untuk menangani PLTA ini harus dilatih atau sekurang-kurangnya diberi penyuluhan sehingga mereka peduli pada kelangsungan operasi nantinya.

Tulisan ini memberikan ulasan tentang pembangkit air sekala kecil tentang teknologi tenaga air dan pentingnya perawatan untuk meningkatkan kinerja pembangkit. Hal yang penting adalah bagaimana sebuah pembangkit air sekala kecil dapat diefektifkan. Optimasi tegangan sistem untuk saluran dan optimasi kapasitas dummy merupakan fokus penelitian ini. 


\section{METODOLOGI PENELITIAN}

\section{II.1 Teknologi Hydropower}

Sumber energi air didasarkan pada siklus alami yang dikategorikan sebagai sumber energi terbarukan. Sumber ini sudah lama dikenal manusia. Air sebagai pembangkit listrik adalah andal dan hemat biaya teknologi [2]. Skema Pembangkit Listrik Tenaga Air (PLTA) adalah fleksibilitas dalam desain dan dapat dirancang untuk memenuhi permintaan beban dasar dengan faktor kapasitas relatif tinggi, atau memiliki kapasitas terpasang yang lebih tinggi.

Tenaga air adalah sumber energi terbarukan terbesar, dan menghasilkan sekitar $16 \%$ listrik Dunia dan lebih dari empat perlima listrik terbarukan dunia. Saat ini, lebih dari 25 negara di dunia bergantung PLTA untuk $90 \%$ pasokan listriknya $(99,3 \%$ di Norwegia), dan 12 negara $100 \%$ bergantung pada hydro. Hydro menghasilkan sebagian besar listrik di 65 negara dan memainkan beberapa peran di lebih dari 150 negara. Kanada, China dan Amerika Serikat adalah negara yang memiliki kapasitas pembangkit tenaga air terbesar [8] [9] [10].

Tenaga air adalah sumber tenaga yang paling fleksibel generasi tersedia dan mampu merespons menuntut fluktuasi dalam hitungan menit, menghasilkan beban dasar daya dan, ketika reservoir hadir, menyimpan listrik selama berminggu-minggu, berbulan-bulan, musim atau bahkan bertahun-tahun [11] dan [8]. Salah satu keunggulan utama PLTA adalah kemampuan "mengikuti beban" yang tak tertandingi (misal dapat memenuhi muat fluktuasi menit demi menit). Meski lainnya tanaman, terutama pembangkit listrik tenaga panas konvensional, dapat merespons fluktuasi pemuatan, waktu responsnya adalah tidak secepat dan sering tidak sefleksibel pita keluaran penuh mereka. Selain fleksibilitas dan keamanan jaringan layanan (spinning reserve), bendungan PLTA dengan besar penyimpanan reservoir digunakan untuk menyimpan energi dari waktu ke waktu memenuhi puncak sistem atau permintaan dipisahkan dari aliran masuk. Penyimpanan dapat berupa hari, minggu, bulan, musim atau bahkan bertahun-tahun tergantung pada ukuran reservoir.

Skema PLTA beragam dalam ukuran dari hanya beberapa watt untuk pico-hydro hingga beberapa GW atau lebih untuk skala besar. Yang lebih besar biasanya akan berisi sejumlah turbin, tetapi yang lebih kecil mungkin hanya mengandalkan satu turbin. Dua pembangkit listrik tenaga air terbesar di dunia adalah $14 \mathrm{GW}$ di Brasil dan Tiga di Cina dengan 22,4 GW. Pembangkit air ini menghasilkan 80 hingga $100 \mathrm{TWh} /$ tahun [8].

Sistem tenaga air yang besar cenderung terhubung grid terpusat untuk memastikan bahwa ada cukup menuntut untuk memenuhi kapasitas generasi mereka. Kecil pembangkit listrik tenaga air dapat, dan sering kali, digunakan secara terisolasi area off-grid atau di mini-grid. Dalam sistem grid terisolasi, jika reservoir besar tidak memungkinkan, musiman alami variasi aliran mungkin mensyaratkan bahwa pembangkit listrik tenaga air dikombinasikan dengan sumber pembangkit lain untuk memastikan pasokan terus menerus selama periode kering.

Tenaga air mengubah energi potensial massa air mengalir di sungai atau aliran dengan vertikal tertentu jatuh (disebut "kepala"). Potensi kekuatan tahunan pembuatan proyek pembangkit listrik tenaga air sebanding dengan kepala dan aliran air. Pembangkit listrik tenaga air menggunakan a konsep yang relatif sederhana untuk mengubah potensi energi dari air yang mengalir untuk mengubah turbin, yang, pada gilirannya, menyediakan energi mekanik yang diperlukan untuk menggerakkan a generator dan menghasilkan listrik (Gambar 1).

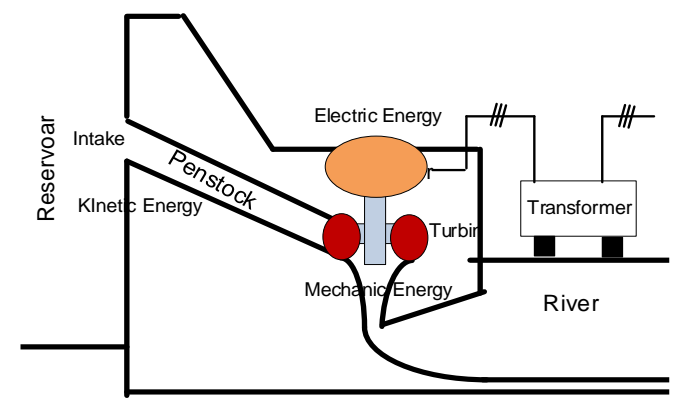

Gambar 1. Skema pusat pembangkit mikrohydro

Ada empat komponen utama dari mikrohydro adalah:

1. Bendungan: Sebagian besar pembangkit listrik tenaga air mengandalkan bendungan yang menahan air, membuat reservoir air yang dapat digunakan sebagai penyimpanan. Mungkin juga ada bak penyaring untuk mengatasi penumpukan sedimen sebelum bendungan.

2. Intake, penstock dan ruang lonjakan (surge chamber): Gerbang di bendungan terbuka dan gravitasi menghantarkan air melalui penstock (capipeline) ke turbin. Terkadang ada sebuah pemicu depan (headrace) sebelum penstock. Ruang atau tangki lonjakan digunakan untuk mengurangi lonjakan tekanan air yang berpotensi merusak atau menyebabkan peningkatan tekanan pada turbin.

3. Turbine: Air mengalir ke bilah turbin dan memutar turbin, yang dihubungkan ke generator oleh suatu poros. Ada berbagai konfigurasi yang dimungkinkan dengan generator di atas atau di samping turbin. Jenis turbin yang paling umum untuk pembangkit listrik tenaga air yang digunakan saat ini adalah Francis Turbine, yang memungkinkan konfigurasi berdampingan dengan generator.

4. Generator: Saat bilah turbin berputar, rotor di dalam generator juga berputar dan arus listrik dihasilkan ketika magnet berputar di dalam generator kumparan tetap untuk menghasilkan arus bolak-balik (AC).

\section{II.2 Perawatan}

Pemeliharaan rutin meningkatkan keandalan operasional dan masa pakai peralatan. Dengan demikian, dari sudut pandang ekonomi, muncul pertanyaan berikut: Sampai titik manakah ekonomis untuk melanjutkan perawatan dan perbaikan, atau mulai kapan akan lebih masuk akal untuk mengganti komponen atau sub-assemblies yang lengkap.

Tanda-tanda keausan dan penuaan mulai muncul dengan meningkatnya waktu pengoperasian peralatan. Penuaan dapat didefinisikan sebagai berkurangnya kualitas teknis yang diperlukan selama perjalanan waktu. Ketika risiko pemadaman yang tidak direncanakan meningkat secara signifikan atau komponen mengalami kegagalan besar, akhir masa hidup tercapai.

Perubahan dalam operasi mempengaruhi proses penuaan, menjadikannya lebih penting untuk secara teratur memeriksa dan menganalisis kondisi pembangkit. Ketika akhir dari umur yang diharapkan tercapai, tindakan pencegahan yang tepat waktu dapat diambil untuk mencegah kegagalan yang tidak terduga. Ini bisa dalam bentuk pekerjaan perbaikan yang dipilih atau penggantian komponen lengkap. 
Prediksi seumur hidup tidak ditujukan untuk menunjukkan dengan tepat akhir masa hidup yang ingin dicapai, yaitu, ini bukan waktu kegagalan total. Ini lebih merupakan ukuran probabilitas kegagalan komponen dalam jangka waktu tertentu. Berdasarkan mode operasi hingga waktu yang dipermasalahkan dan temuan diagnostik, dapat digunakan untuk memperkirakan risiko kegagalan di masa mendatang secara lebih akurat.

Manfaat dari perawatan akan mempertahankan umum hidup peralatan seperti yang ditunjukkan oleh gambar 2 dan gambar 3 . Gambar 2 adalah kondisi peralatan yang dirawat dengan baik sehingga umur hidupnya dapat bertahan selama periode 2 . Sedangkan gambar 3 adalah peralatan yang tidak dirawat dengan baik. Peralatan akan mengalami pengurang umur yang signifikan, yaitu hanya sampai pada pertengahan periode 2 saja.

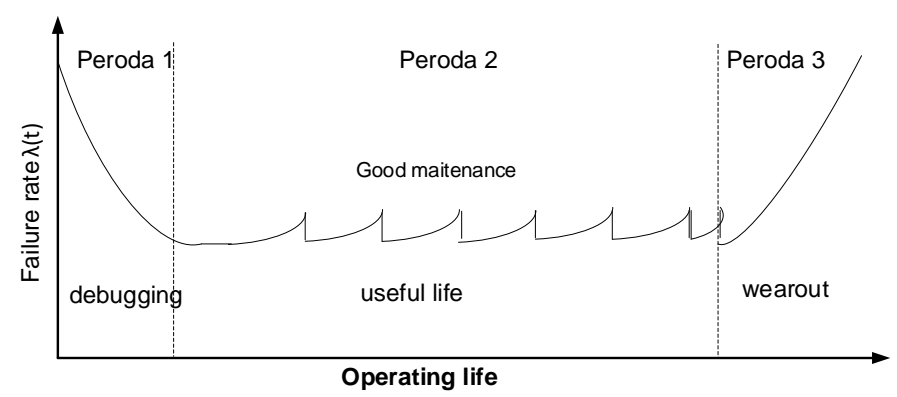

Gambar 2. Peralatan yang terawat dengan baik

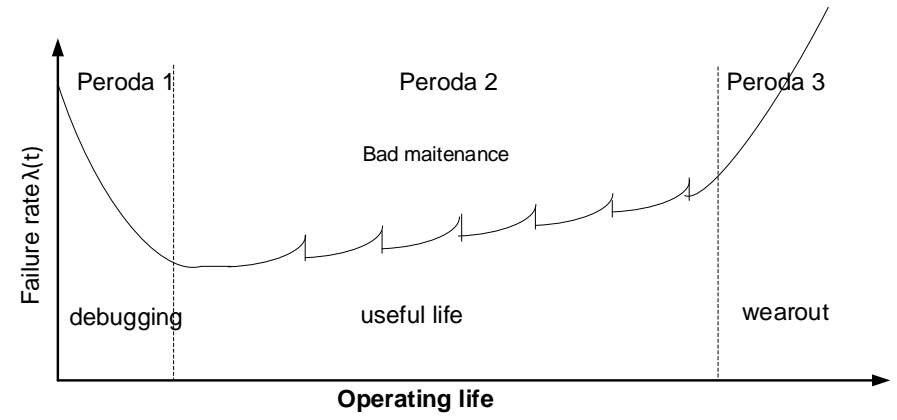

Gambar 3. Peralatan yang tidak terawat dengan baik

\section{KUALITAS LISTRIK}

\section{III.1 Tegangan Jatuh}

Tegang jatuh adalah salah kualitas pasokan daya yang harus diperhatikan pada PLTA kecil tenaga. Lokasi potensi tenaga air sangat ditentukan oleh geografis, baik lokasi air terjun atau sungai. Dilain pihak perkampungan juga dapat terletak pada lokasi yang berbeda dengan jarak yang cukup jauh dari potensi tenaga air. Daya listrik yang dikirim dari suatu tempat ke tempat lain akan mengalami penurunan tegangan. Bila penurunan sangat tajam akan menjadikan kualitas tegangan di sisi pemakai menjadi sangat jelek, sehingga daya listrik tidak dapat digunakan. Secara umum level tegangan antara suplai dengan beban dari sistem distribusi adalah $+5 \%$ dan $10 \%$ [12]. Namun dalam penentuan tegangan jatuh ini harus didasarkan pada efisiensi jaringan. Gambar 4 adalah sebuah pembangkit menyalurkan dayanya melalui penghantar dengan impedansi $\mathrm{Z}=\mathrm{R}+\mathrm{j} \mathrm{X}$.

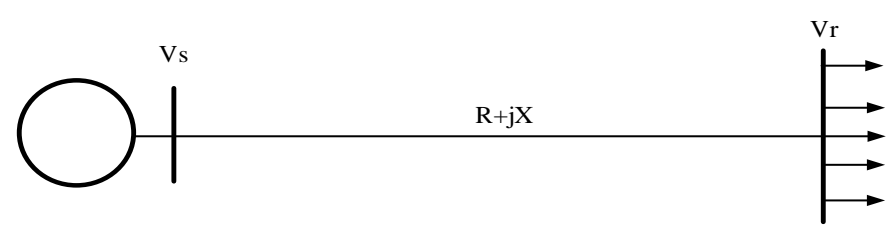

Gambar 4. Sistem jaringan terisolasi

Bila daya yang dikirim ke beban oleh pembangkit melalui penghantar adalah,

$S_{s}=P_{s}+j Q_{s}$

Bila diinginkan efisiensi penghantar adalah $\eta$, maka arus yang lewat penghantar adalah,

$I=\sqrt{\frac{(1-\eta) P_{s}}{R}}$

Tegangan jatuh dapat

$\Delta V=Z \sqrt{\frac{(1-\eta) P_{s}}{R}}$

Persamaan 3 menyatakan hubungan antara tegangan jatuh dengan efisiensi penghantar yang ditunjukkan dalam Gambar 5.

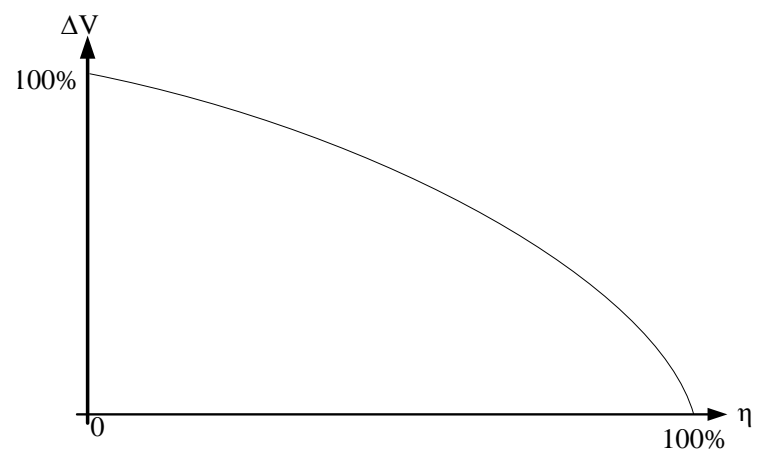

Gambar 5. Hubungan tegangan jatuh dengan efisiensi

Sementara pada sistem tiga tegangan jatuh pada penghantarnya adalah,

$\Delta V=Z \frac{S_{s}}{\sqrt{3} V_{s}}$

Dari persamaan 3 dan 4 diperoleh tegangan adalah,

$V_{s}=\frac{S_{s}}{\sqrt{3}} \sqrt{\frac{R}{(1-\eta) P_{s}}}$

Bila diasumsikan faktor daya adalah 0,8 , maka persamaan 5 disederhanakan menjadi persamaan 6 .

$V_{s}=0,722 \sqrt{\frac{R P_{s}}{(1-\eta)}}$

Pengaruh impedansi pengantar dapat ditunjukkan oleh Gambar 6. Impedansi semakin kecil maka tegangan sistem akan semakin rendah. Ini disebabkan oleh tegangan jatuh pada pengantar lebih kecil pada efisiensi pengantar yang sama. 


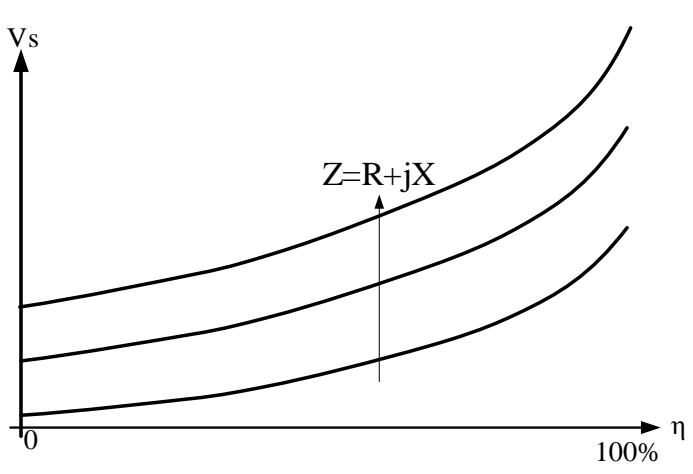

Gambar 6. Hubungan tegangan sistem dengan efisiensi

\section{III.2 Kontrol Tegangan dan Frekuensi}

Operasi PLTA kecil adalah sangat sederhana dari PLTA besar, dimana PLTA kecil memiliki sudu turbin yang tetap. Semua air melalui turbin dikonversikan menjadi tenaga mekanik oleh turbin yang diekspresikan oleh persamaan 7 .

$P_{m}=\eta \rho g h Q$

Dimana $\eta$ adalah efisiensi yang dipengaruhi oleh ruang udara dan kapitasi air, $\rho$ adalah masa jenis air, $g$ adalah gravitasi, $h$ adalah tinggi air jatuh dan $Q$ adalah debit. Dalam studi PLTA kecil semua parahanya debit yang dianggap sebagai variabel sehingga daya output turbine adalah konstan dan kecepatan turbin dapat dinyatakan konstan yang dihitung melalui persamaan 8 .

$\omega=\frac{P_{m}}{T}$

Dimana $\omega$ adalah kecepatan dan $T$ adalah torsi. Sedangkan tegangan teminal generator adalah,

$V=E-j X I$

Diman $\mathrm{X}$ adalah reaktansi generator, I adalah arus jangkar dan $E$ adalah gaya gerak listrik yang formulasinya adalah,

$$
E=k f
$$

$\mathrm{k}$ adalah konstanta yang tergantung pada fluksi dan ukuran fisik generator dan $\mathrm{f}$ adalah frekuensi.

Dari persamaan 9 dan 10, bila I dan $\mathrm{f}$ adalah konstan, maka tegangan terminal $\mathrm{V}$ juga konstan. Untuk mempertahankan kondisi ini maka beban generator harus dikondisikan selalu kontan. Dalam tulisan ini mempertimbangkan beban dummy di samping beban konsumen (beban riil), yang ditunjukkan oleh Gambar 7.

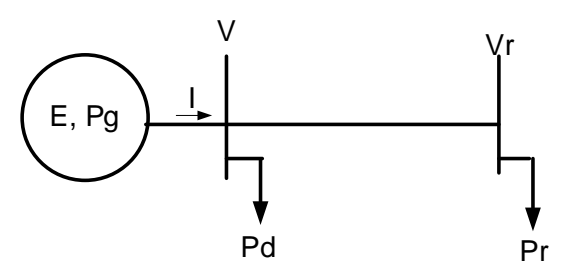

Gambar 7. Kontrol generator untuk beban tetap

$P_{g}=P_{d}+P_{s}$

Dalam Kawasan waktu pengontrolan daya keluaran generator tetap diilustrasikan dalam Gambar 8. Kurva-kurva daya dalam Gambar 8 ini sudah memenuhi persamaan 11. Dengan pola operasi ini, tegangan dan frekuensi generator adalah tetap sesuai dengan generator.

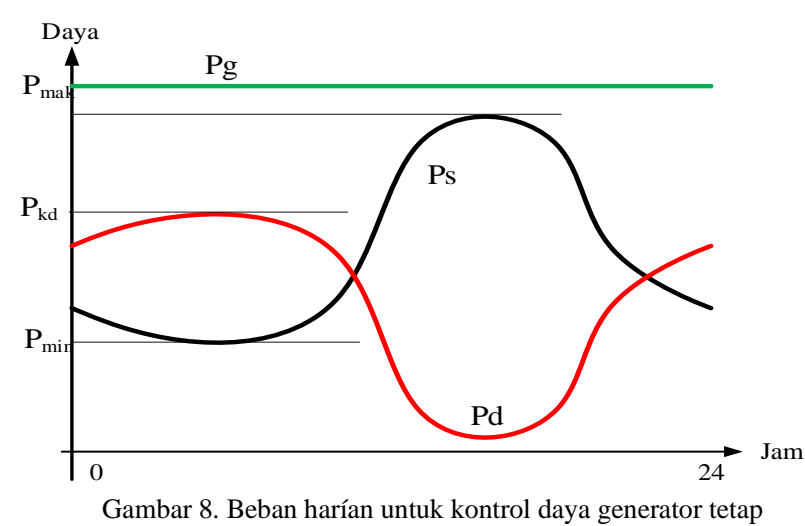

Berdasarkan beban harian ini diperoleh beban puncak adalah $\mathrm{P}_{\text {mak }}$, beban minimum adalah $\mathrm{P}_{\min }$ dan kapasitas beban dummy maksimum adalah $P_{k d}$. Gambar ini menunjukkan bahwa kapasitas beban dummy dapat dioptimalkan yang diturunkan dari Gambar 8, yaitu:

$P_{k d}=P_{g}-P_{\min }+P_{t l}$

Dimana $P_{t l}$ adalah daya toleransi dengan nilai sebagai berikut.

$0 \leq P_{t l} \leq \frac{P_{\text {mak }}+P_{\min }-P_{g}}{2}$

Idealnya $P_{t l}=0$, namun perlu diambil nilai yang lebih besar untuk mengatasi keakuratan desain. Dalam tulisan ini disarankan secara rule of thumb nilai adalah,

$P_{t l}=0.05 P_{\min }$

\section{STUDI KASUS}

Untuk menunjang metode yang diusulkan maka PLTMH di Pesantren Suryalaya diambil sebagai bahasan studi dalam tulisan ini. Ini adalah studi kasus yang menarik karena drop tegangan yang tinggi akibat jarah PLTM dengan lokasi pesantren yang cukup jauh.

Data generator PLTMH adalah 380/220 V, $50 \mathrm{~Hz}$ dan $60 \mathrm{kVA}$; Kapasitas beban dummy adalah $50 \mathrm{~kW}$; Sedangkan saluran menggunakan kabel inti tunggal dengan spesifikasi NFA2X-T $3 \times 70+1 \times 50 \mathrm{~mm} 2,0,6 / 1 \mathrm{kV}$ dengan jarak saluran diperkirakan 3,25 $\mathrm{km}$. Hasil perhitungan tegangan di sisi penerima (lokasi pesantren) untuk variasi daya ditunjukkan dalam gambar 4. Hasil ini menunjukkan bahwa daya yang dapat diserap oleh pesantren adalah $15000 \mathrm{kVA}$ atau $12 \mathrm{~kW}$ untuk drop tegangan 10\%. Pada kondisi ini tegangan di lokasi pesantren adalah $346.4 / 200 \mathrm{~V}$, dimana besar tegangan ini sudah memenuhi spesifikasi peralatan listrik.

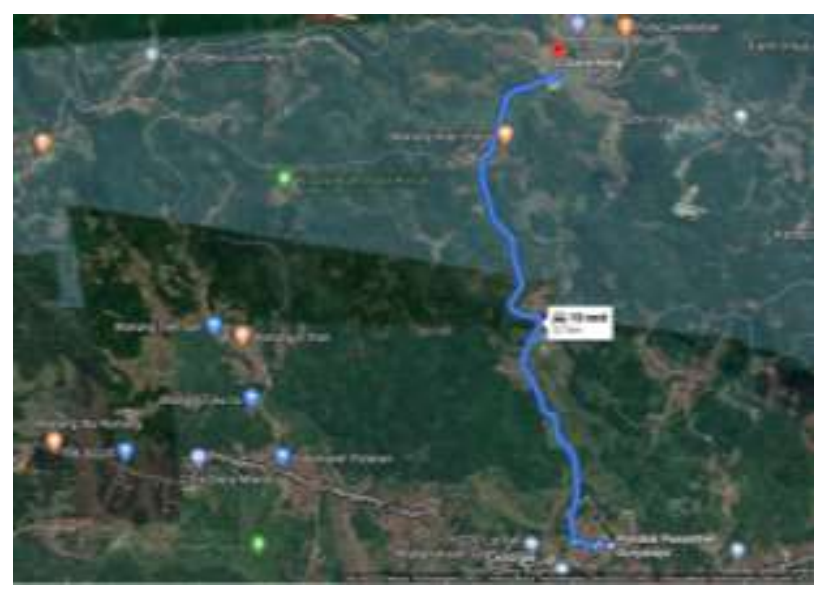

Gambar 9. Peta lokasi (Courtesy: Google map) 


\begin{tabular}{|c|c|c|c|}
\hline Jurnal Energi & Volume 11 Nomor 1 & November 2021 & ISSN: 2089-2527 \\
\hline
\end{tabular}

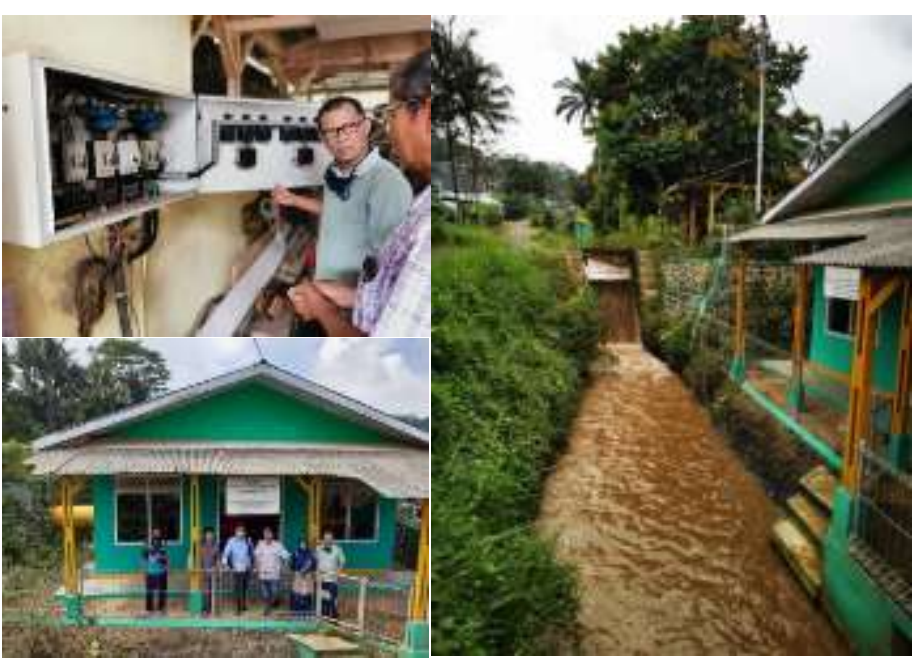

Gambar 10. Foto Peninjauan Lokasi PLTMH

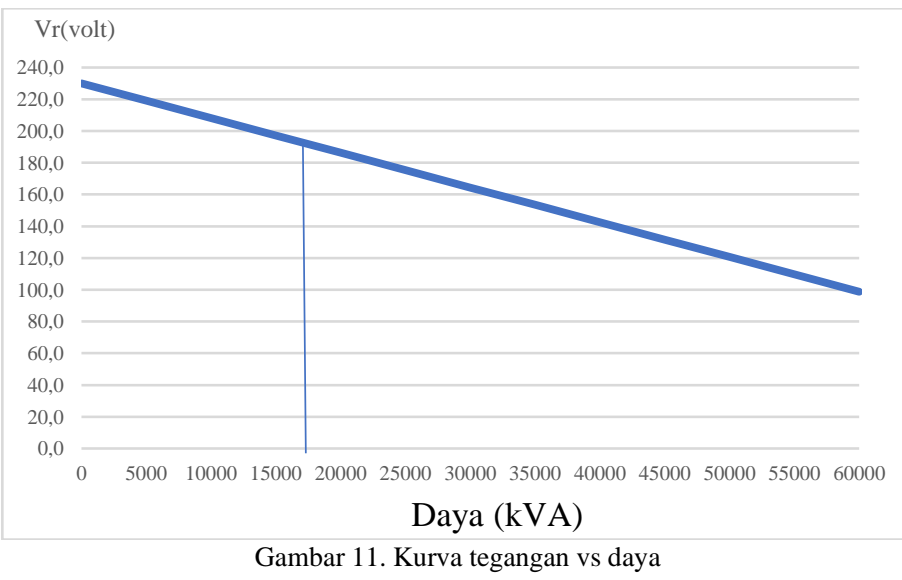

Karena total beban di pesantren lebih dari $12 \mathrm{~kW}$ maka PLTMH tidak maksimal dimanfaatkan oleh pesantren. Jadi daya sebesar 36 $\mathrm{kW}$ tidak bisa dimanfaatkan karena bila dimanfaatkan maka tegangan akan turun menjadi $173.2 / 100 \mathrm{~V}$, dimana tegangan sebesar ini tidak memenuhi standar peralatan listrik. Untuk mengefektifkan PLTMH tersebut perlu dinaikkan tegangan sistem salurannya. Gambar 11 adalah hasil perhitungan tegangan sistem terhadap rugi-rugi dan drop tegangan. Dari gambar ini diperoleh untuk sandar drop tegangan sebesar 5\% tegangan sistemnya adalah 780 volt. Sedangkan standar rugi-rugi $4 \%$ jatuh pada tegangan sistem 950 volt. Setelah itu kurva rugi-rugi dan drop tegangan turun secara landai dan pada tegangan sistem $1 \mathrm{kV}$ drop tegangannya adalah $2,8 \%$ dengan rugi-rugi $3,75 \%$ dan di tegangan sistem $1,5 \mathrm{kV}$ drop tegangan adalah $1,3 \%$ dengan rugirugi $1,6 \%$.

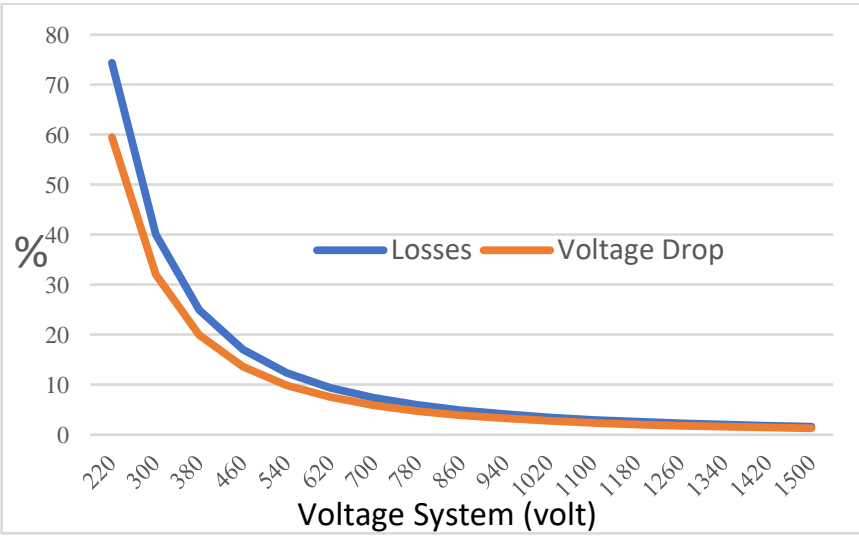

Gambar 10. Rugi-rugi dan Drop tegangan vs tegangan sistem
Beban puncak dan beban terendah adalah $45 \mathrm{~kW}$ dan $20 \mathrm{~kW}$. Sedangkan kapasitas beban dummy $50 \mathrm{~kW}$. Ideal kapasitas beban dummy yang dihitung melalui persamaan 12 adalah $26 \mathrm{~kW}$. Besar beban dummy $50 \mathrm{~kW}$ tersebut sudah sangat mencukupi.

\section{KESIMPULAN}

Tulisan ini telah mengajukan untuk mengefektifkan kinerja dari suatu pembangkit tenaga air berskala kecil. Hal yang perlu diperhatikan adalah perawatan dan kualitas listrik yang diterima oleh beban. Perawatan rutin harus dilakukan dengan baik dan teratur sehingga performa PLTMH dapat dipertahankan sampai pada umur peralatannya. Metode untuk menentukan tegangan sistem dan beban dummy telah diajukan dalam tulisan ini, dimana kualitas tegangan dan frekuensi keluaran generator dipertahankan dengan beban tetap melalui beban dummy yang terkontrol. Tegangan sistem saluran di optimasi melalui standar drop tegangan dan persentase rugi-rugi, yaitu drop tegangan 5\% dan rugi-rugi saluran $4 \%$ diambil sebagai acuannya. Studi kasus pada PLTMH Suralaya pada kondisi awal hanya dapat menyerap daya $12 \mathrm{~kW}$ pada tegangan $220 \mathrm{volt} / \mathrm{phasa}$ dan daya sebesar $36 \mathrm{~kW}$ tidak terserap. Supaya daya PLTMH $48 \mathrm{~kW}$ dapat diserap maka tegangan sistem saluran harus dinaikkan menjadi $1 \mathrm{kV}$ dan ini telah memenuhi standar drop tegangan dan rugi-rugi saluran. Hasil kajian diperoleh kapasitas optimal beban dummy adalah $26 \mathrm{~kW}$ dan ini lebih kecil dari beban dummy yang terpasang yaitu $50 \mathrm{~kW}$.

\section{UCAPAN TERIMA KASIH}

Ucapan terima kasih disampaikan kepada Program Penelitian DIPA Pusat Penelitian dan Pengabdian Masyarakat (P3M) Politeknik Negeri Bandung tahun 2020, atas bantuan dana yang telah diberikan.

\section{DAFTAR PUSTAKA}

[1] I. G. Widodo, A.Surnaso, Agato, H. Sihombing dan D. Sulistiono, "Pengaruh Kedalaman Pencelupan Sudu Kincir Terhadap Unjuk Kerja Kincir Air". Indonesia Paten CCBY-NC-SA 4.0, 2020.

[2] irena.org, "Renewable Energy Technologies: Cost Analysis Series - Hydropower," IRENA WORKING PAPER, vol. 1, no. 3/5, June, 2012.

[3] PLN, Rencana Usaha Penyediaan Tenaga Listrik (RUPTL) 2019 - 2028, Jakarta: PT PLN (Persero), Februari, 2019.

[4] S. Singh dan M. P. Upadhyay, "Study of Different Issues and Challenges of Small Hydropower Operation," dalam International Conference on Advances in Energy Conversion Technologies (ICAECT), Manipal, India, 2014.

[5] L. M. Parera, Microhydro Power Plant, Future Energy Source, Researchgate, 2018.

[6] D. Sodiq dan A. Susanto, Perancangan dan Pembuatan Alat Sinkronisasi Otomatis Pembangkit Listrik Tenaga Mikrohidro dengan Sistem Jaringan PLN, Yogyakarta: UGM, 2004.

[7] H. Zein, J. Raharjo, C. K. Wachjoe dan A. D. Mulyadi, "A Method for Estimating Technical Losses in Primary Feeder Conductors," International Review on Modelling and Simulation (IREMOS), vol. 13, no. 2, 2020.

[8] IPCC, "Renewable Energy Sources and Climate Change 
Mitigation," Cambridge University Press, New York, 2011.

[9] REN21, "Renewables 2011: Global Status Report," www.ren21.net, 2011.

[10] IHA, "International Hydropower Assocition World Congress on Advancing Sustainable Hydropwer," IISD, 2011.

[11] A. Brown, S. Müller dan Z. Dobrotková, Renewable Energy
Market and Prospects by Technology, Paris: International Energy Agency (IEA), November 2011.

[12] SPLN-72, Spesifikasi Desain untuk Jaringan Tegangan Menegah (JTM) dan Jaringan Tegangan Rendah (JTR), Jakarta: PT PLN (Persero), 1987. 